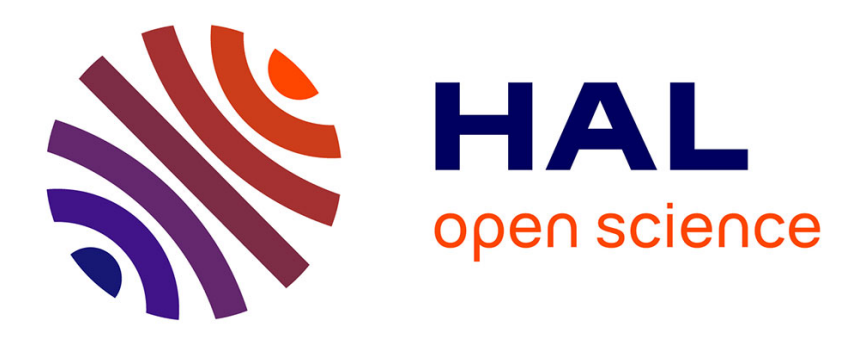

\title{
Crop management for processing tomatoes in the year 2000
}

\author{
Y. Dumas
}

\section{To cite this version:}

Y. Dumas. Crop management for processing tomatoes in the year 2000. 4. International Symposium, Feb 1991, Mendoza, Argentina. hal-02773003

\section{HAL Id: hal-02773003 https://hal.inrae.fr/hal-02773003}

Submitted on 4 Jun 2020

HAL is a multi-disciplinary open access archive for the deposit and dissemination of scientific research documents, whether they are published or not. The documents may come from teaching and research institutions in France or abroad, or from public or private research centers.
L'archive ouverte pluridisciplinaire HAL, est destinée au dépôt et à la diffusion de documents scientifiques de niveau recherche, publiés ou non, émanant des établissements d'enseignement et de recherche français ou étrangers, des laboratoires publics ou privés. 
Number 301 January 1992
ISHS

International Society for Horticultural Science

\section{Fourth International Symposium on Processing Tomatoes}

Editors

Cosme A. Argerich

Humberto R. Galmarini

Mendoza, Argentina

18-21 February, 1991 


\title{
CROP MANAGEMENT FOR PROCESSING TOMATOES IN THE YEAR 2000
}

\author{
Y. Dumas \\ Institut National de la Recherche Agronomique, Station d'Agronomie, B.P. 91,
F 84143 Montfavet Cedex
}

\section{Introduction}

It is hazardous to try to envision the next ten years because changes do not occur at the same rate in the various countries concerned by processing tomato : and yield increase as their main objective, with non-mechanized production and quality as a new concern. Ten years is, and others with developed techniques represents the time required to disseminate a long and short period. It roughly progress (such as drip irrigation) disseminate new technology. But technological appear within some fields, such as the new to accelerate. Many changes may also purchasers. Ten years may seem short for requirements of the processed product creating and distributing a new cultivar may concerns such as plant-breeding: tomato crop management look like in thar may take a decade. So, what will the

In the following sections, not all year 2000 ?

examined in detail. After an evocation all the crop management techniques are important points of the crop management changes in the general cropping context, tomato development phases.

\section{General context}

As for other crops, success in processing tomato management requires more and more precise methods and techniques and is becoming a difficult exercise, at 2000 , it will be necessary to face various anced areas. Looking forward to the year future. The following three determining aspects can which will govern the crop's

\subsection{Crop mechanization}

Crop mechanization will widely spread. Of course this will vary in relation to the very different cropping systems used throughout the world (Portas et al, especially labour, which result of the general need to reduce production costs, (Table 1). The future in crop ase much more rapidly than the tomato selling price once-over harvest, more and more by mant also tends towards an increased use of a both at the medium and stand levels, which. This leads to cultivation constraints consequently technical choices (Di Candilo determine agronomic objectives and Dumas, 1990 a).

extension must be accompanied processed as soon as it is ripe, single harvest (Lecocq and Vayson, 1985) to supply the pronization of raw material production such as in California, but also to properly docessing plants for a fairly long time, growing season. This requires a sequential harve farm work throughout the settlement planning. This type of planning is efficient in programme and crop stable climate and will be more critical in areas with in areas with regular and climate, such as in the South-East of within a 45 day interval may be harvested within (Table 2) where two fields seeded been cold and summer hot. 


\subsection{Control of raw material quality}

Raw material quality, i.e. all the characteristics of tomatoes delivered to the processing plant, will become an objective per se. Various types of products will have to be elaborated in the fields, depending on their processing destination and crop management will need to be adapted to obtain the desired product. The main quality parameters are soluble solids, $\mathrm{pH}$, colour, insoluble solids and soluble pectins. But very restrictive quality standards will soon have to be met for nutrition (mineral elements, vitamins), taste (acids) and health standards (bacteriology and
toxicological harmlessness).

A change in focus will occur. Until now, maximum quantitative yields were aimed at, and, more recently, high yields at the lowest cost, which generally resulted in lower production levels. In future it will be necessary to know how to produce fruit with a high given quality probably by decreasing quantitative yield.

\subsection{Respect for natural resources and environment}

It will be necessary to produce without pollution. An increasing public awareness of environment and natural resource problems has developed groundwater and to be also major consumers of energy and water which must be conserved. Processing tomato crop management will require an effort in input management (supply reduction and increased use efficiency) in relation to production goals, instantaneous crop and medium states and their probable
changes over time.

This is the framework which will have to be taken into consideration by processing tomato crop management in the various physical and socio-economic situations, as production will only thrive if it continues to provide sufficient returns for the grower. The tendency is to use a crop management for a given production margins. Farming is thus becoming of these two parameters has its own change though fixed in advance, can possibly change which disturb the production achievement.

\section{Crop management}

Crop management must be considered as a consistent whole with regard to production aims, initial crop conditions and intermediate stages or objectives eventually fixed by the grower which are to be achieved through the available means, i.e. work organization on the farm, equipment, funds and information.

To simplify the presentation in relation with yield components, the tomato development cycle can be schematically divided into three main interdependant
phases (Table 3) :

- Stand establishment and vegetative growth phase : this determines the number of plants per area unit, the stand structure and an earlier or later flowering.

Flowering and fruit-setting phase : it leads to the number of fruits per plant and, along with the previous phase result, determines the number of fruits per area unit, which is the main quantitative yield component.

- Ripening phase: at the end of this phase average fruit weight and its technological characteristics are fixed. In fact, fruit growth overlaps the last two
phases.

Crop management must aim at satisfying the goals of each phase to obtain the final desired product in a crop suited to a single harvest, particularly by machine. The grower will have to think of the management of each phase according to the others. For convenience's sake, crop management elements are 
presented here phase by phase while the main aspects and interactions are
emphasized.

\subsection{Vegetative growth phase}

All the technical operations occuring before or accompanying crop establishment are of primary importance due to their consequences on the medium which largely influence crop potential. The objective is to obtain a stand with a uniform development stage and spatial regularity whose growth and development rate is as close as possible to the potential rate determined by climatic conditions (intercepted energy).

\subsubsection{Crop establishment}

For crop settlement, transplanting and seeding on raised beds will remain complementary methods with equivalent yield potentials (Gerber, 1981).

Transplanting will be more and more achieved with plant-tray seedlings using automatic machines. Growing them in nurseries remains technically rather difficult and expensive but permits a fairly good delivery schedule. Establishment operations must therefore be performed carefully, particularly with the expansion
of hybrids.

Direct-seeding is already used $100 \%$ of the time in certain regions with a suitable climate (California). Because of the necessity of saving costs and labour organization it will be largely extended to numerous regions whose warm season is long enough. In suboptimal conditions, germination, emergence and plant establishment represent critical periods on which the production potential depends. Seeds must be placed under favourable conditions somewhat close to the nursery conditions. Many studies have shown the advantages of seed priming which could spread. Priming with potassium nitrate or phosphate enhances seed vigour i.e. germination rate (Argerich and Bradford, 1989, Argerich et al., 1990) and reduces emergence time (Leskovar and Sims, 1987) particularly under low temperature conditions (Barlow and Haigh, 1987). It is a way to make emergence more uniform and to obtain a more homogeneous stand, although an initial growth advantage does not necessarily improve ripening time, total yield or fruit sugar content (Alvarado et al., 1987). The physiological mechanisms involved in priming are not well known. Haigh and Barlow (1987) found that germination was more solution. The various efficient than on the osmotic potential of the imbibition enzyme system activity during the first germight exert a stimulating effect on 1974).

Seedling establishment also depends on physical characteristics of the seedbed. In addition to good temperature conditions and moisture content, maintaining a soil structure conducive to water and air movement and to seedling emergence is very important. On easily crusting soils it is necessary to protect the seed-bed by applying a plastic mulch or soil conditioner. The latter may produce a synergic effect on the plant mineral nutrition (Wallace and Abouzamzam, 1986).

Mineral nutrition: The tomato plantlet is autotrophic a few days after emergence (Suniaga and Dumas, 1990), as nitrogen and phosphorus absorption begins on the day of emergence when photosynthesis starts after potassium absorption has already began. During the period of time until flowering mineral nitrogen availability in the medium influences growth and development (Suniaga Quijada, 1990) : too little $\mathrm{N}$ in the solytion (e.g. $2 \mathrm{meq} \mathrm{N}{ }^{-1}$ ) results in a general delay, and too much (e.g. 18 meq $\mathrm{N} \mathrm{I}^{-1}$ ) first causes root growth rate to decrease and then yields a great number of small non-viable trusses. It thus seems very important to know the mineral $N$ content of the soil to control it, both to correctly 
manage the crop and to avoid waste. It is also known that a high $\mathrm{P}$ availability in the soil increases growth and development rates, particularly from emergence to early flowering. However, the root system is very small during the vegetative phase and it is not necessary to enrich the entire arable soil volume : banding a moderate amount of triple superphosphate under the seeds is sufficient to achieve the required effect (Dumas,1989). A high individual growth rate is advantageous in competition against weeds on the row. Banding low amounts of $N$ fertilizer on the rows at the first truss stage is very efficient for young tomato seedlings and disadvantages nitrophilous weeds which emerge off the rows.

Plant spatial distribution (arrangement and density) may strongly influence yield potential, but it depends on the cultivar vine-size (Frost and Kretchman, 1988). Growing a compact plant type at high density on double rows results both in a more rapid and important soil covering. Consequently, the stand intercepts more light. Within certain limits tomato is able to compensate for density variations by varying branch number and then the numbers of truss and fruit per plant. But Figure 1 indicates that the capacity of a seeded stand to compensate is highly dependant on the medium conditions and stand density largely influences fruit number (main yield component), as well as, to a lesser extent, average fruit weight. Therefore, it is not easy to choose a density objective or to decide how to manage adjustments in a field, where density is thought to be inadequate. Nichols et al. (1973) have shown that the yield-density relation is of course dependant on the cultivar and that the concentration of maturity increased with the stand density. High density and double-row methods may be revised when using expensive hybrids and large-vined and high solid cultivars (May et Valencia, 1990) or to ensure better crop protection. Stand deficiencies in plantations may lead to a decrease in yield potential. Stoffella and Maynard (1988) have found that replanting was profitable only with $30 \%$ stand reduction in a stressed environment and if it was performed within two weeks after initial transplanting.

\subsubsection{Crop protection}

Pest control : Crop protection will first of all aim at preventing seedlings or transplants from being cut by predatory animals or destroyed by fungus. There is no way to forecast infestation levels and the only thing to do is to perform a preventive pest control preferably with banded applications and low volumes per hectare placed close to the organs to be protected. For leaf pests, sprays should be used in accordance with warnings and field observations based on infestation thresholds when they are known (Bues et al., 1985). For example, the more vigorous the crop, the higher the aphid infestation threshold may be (Dumas, 1990 a).

Weed control: Weeds are generally well controlled in transplanted fields, but weed control is a major problem in seeded fields. It is often reported that the critical period for weed competition is from 30 to 45 days after seeding date (Duranti and Carone, 1983). Yield losses associated with weed quantity could be attributed both to reductions in light levels because of shading and to competition for water resulting in stomatal closure (Weaver and Tan, 1987).

Although weeds such as Amaranthus retroflexus L. and Echinochloa crus galli L. are the most aggressive against tomato (Caussanel et al., 1989) the "Solanum sp." complex, particularly black nightshade (Solanum nigrum L.) pose the greatest problems in seeded crops due to the biological density factor (Branthome, 1990). A hyperbolic model provided an excellent fit to data on tomato yield losses, which were lower for sown tomatoes grown at higher density (45 000 against 33300 plants $\mathrm{ha}^{-1}$ ) in twin rows, as a function of nightshade density (Weaver et al., 1987). Yields were significantly reduced at infestation levels above 1 plant $\mathrm{m}^{-2}$ (Damato and Montemurro, 1986) and Caussanel et al. (1989) showed that 3 plants $\mathrm{m}^{-2}$ from 
the tomato stage of 3-5 leaves to harvest were sufficient to reduce yields by 35 $45 \%$. The most critical period of interference was found to be from early flowering through fruit-set with a threshold of less than 1 plant $\mathrm{m}^{-2}$. It is necessary to develop control schedules adapted to cultural situations during the vegetative phase: emergence in clean soil, maintaining low populations and total cleaning before flowering. Presently there is no chemical solution which completely destroys nightshades without reducing tomato yield. Control depends on strategies consistent with crop specificities (Branthome, 1990), e.g. use of mixtures of pre- or post-emergence herbicides combined with complete diquat applications before tomato emergence or banded diquat applications later and with hoeing. Localized soil desinfection is efficient during stand establishment. Mechanical or hand hoeing also helps remove crusts and favours water and air circulation through the soil, although superficial roots must be preserved.

The next step will be genetic. Currently no useful natural tolerance to postseeding or post-emergence herbicides efficient against Solanum nigrum L. have been found in genus Lycopersicon (Damidaux et al.,1990). Resistances to certain efficient herbicide molecules will undoubtly be introduced soon into the tomato genome using biotechnology. However, one must take care not too over privilege strategies which could limit the range of cultivar choices for growers and lead to a more and more intense use of herbicides. Other methods have to be explored, such as biological control by weed parasitism (Putman, 1990, Giannopolitis and Chrysayi, 1989, cited by Branthome, 1990). Management solutions for the very near future must be based on integrating cultural and chemical methods : crop successions, soil preparation, banding of adapted fertilizer amounts, hoeing and banded applications of herbicide allowing spray volume savings. Unfortunately, the best way to water young tomato seedlings or transplants to achieve good stand establishment remains sprinkler irrigation which favours weed emergence and development!

\subsubsection{Soil structure and rooting}

Under common management conditions, potential yields widely depend on root system extension (Dumas, 1982) through the level and regularity of water and nutrient supply. Root depth and distribution depend on structure and porosity of the various soil layers. For three contemporary seedling (UC 82) situations on nutrient-rich loamy-clay soils in the South-East of France, Figure 2 shows the root depth changes over time and the soil bulk density values measured between -5 and $-60 \mathrm{~cm}$. Situation (a) presented favourable soil structure conditions and root growth rate was high. At the 1st truss stage, the taproot point was $40 \mathrm{~cm}$ deep, i.e. four times the shoot height; yield potential was $90-100 \mathrm{tha}^{-1}$. In situation (b) the soil was a bit more compact below $-20 \mathrm{~cm}$ and root growth, rate was lower and final rooting depth smaller. Yield potential was $60-70 \mathrm{t} \mathrm{ha}^{-1}$. Situation (c) represented poor rooting conditions with a taproot point no deeper than $15 \mathrm{~cm}$ at the first truss stage which was also delayed. The soil profile showed a drastic compaction in the ploughed layer from -10 to $-30 \mathrm{~cm}$ and a typical plough-pan between -30 and $-40 \mathrm{~cm}$, with bulk densities $>1.70 \mathrm{~g} \mathrm{~cm}^{-3}$ able to completely stop root system progression, as Greig et al. (1964) observed, and similar to responses obtained by Ruff et al. (1987) in studies on root yolume restriction in containers. Under such field conditions no more than $30 \mathrm{tha}^{-1}$ could be expected.

Thus, soil structure is very important as a basic condition of crop success. Many problems can occur as a consequence of using heavier and more powerful equipment with increased mechanization. Soil moisture conditions during traffic or tillage operations play an essential role in structure discontinuities. Both for current soil tillage (choice of equipment, timing) and correction of structure accidents (e.g. subsoiling a plough-pan), decisions must be made through the 
observation of the soil profile and utilization of simple predictive models which
have to be improved region by region.

Soil profile characteristics must allow the best transplant and seed settlement and rapid plantlet growth to yield a vigorous stand as well as remaining favourable
to the following reproductive phase.

\subsection{Flowering and fruitusetting phase}

It corresponds to the period of the highest rate of dry matter accumulation and plant requirements. The aim generally is to maximize the rate of appearance of fruiting sites on the plant over a month and to subsequently allow fruit growth During this phase, the most limiting agronomic factors may be water and nutrients.

\subsubsection{Nutrient supply}

Plants take up nutrients from the soil solution which is supplied by soil reserves and fertilizers. Actually, it is not possible to exactly know the soil feeding capacity for the various nutrients at a given moment (Dumas, $1990 \mathrm{~b}$ ) and Nevertheless, it is necessary much fertilizer to supply and how to supply it. to meet their momentany and to provide crops with sufficient amounts of nutrients due to leaching or insolubilisation. concentration in the functioning rion. In fact, it is more a question of nutrient total soil volume. Greenwood root volume of soil at any given moment than in fertilizer by various vegetable et al. (1989) found that apparent recovery of $N$ behaviour contrasts vetable crops declined with the increase in $N$ fertilizer; this Gramineae and was explaine well-known constancy of apparent recovery in the a less extensive root system. This is a reat terms of differences of root density due to system to intercept more NO Widders and Lorenz (1979) attributed to the avoid potassium deficiency which systems of the determinate attributed to the inability of the relatively small root the demands of the concentrated fruit set.

In the near future, basic knowledge of the dynamic of the main soil nutrients is expected to increase and lead to an understanding of the general variation rules which will permit fertilization forecasts according to stand requirements. Direct (Coltman, 1987) -if they are sufficiently sensitive as nitrate tests in petiole sap reacts very quickly to nitrate content variations of precise and reliable--, as tomato al., 1991, same issue).

\subsubsection{Water supply}

Processing tomatoes are cultivated only in open field i.e. in regions with a sufficiently long warm season and generally a high water deficit. Therefore it is not surprising that more than two thirds of the areas are irrigated (Portas et al., 1990) and this proportion will increase. Irrigation management depends on many interacting factors : climate characteristics, soil texture and structure, crop potential), irrigating (water demand), rooting system extension (water extraction recipe can be given for quantity and frequency of water quality and availability. No crop coefficient value reaches 1.20-1.30 during full fruit-setting.

continue to Furrow irrigation, the most ancient irrigation system, will undoubtly fields because of its low well-supplied with good quality water and well-levelled optimal water distribution in the fields to provide better homogeneity and limit 
leaching. It needs a porous soil structure to permit good lateral diffusion of water to moisten the beds in the rooting zone.

Sprinkler irrigation is a very common method but one which has disadvantages : it is labour consuming, sensitive to wind, favours soil crusting, weed emergence and desease expansion, and delays traffic. However, it is nearly indispensable to crop establishment in dry years : filling soil to water capacity, germinating seeds, transplant recovery, herbicide fixation. Farmers who use a localized method afterwards must be equipped with both systems.

Drip irrigation systems are recommended when water is limited or expensive and for shallow soils. During the last fifteen years many studies have demonstrated the interest of micro-irrigation as compared to other systems. It often improves yields while saving water (higher use efficiency), particularly in arid regions, it is less favourable to certain pests and permits mechanized handling operations. When it is controlled by an automatic station it requires a large
surrounding area, which is not possible everywhere. Phene et al. (1987) have widely experimented on permanent subsurface drip installations below plough depth. Among its main advantages are: it requires less labour than surface installations, may last longer, keeps the whole soil surface dry, reduces the occurrence of soil born diseases, enhances circulation even while irrigating and allows a more efficient use of water and nutrients resulting in very high yields (Phene et al., 1990). Grattan et al. (1988) observed that it resulted in lower weed
populations, but this was obtained in a region without frequent rains and during a
period of low weed emergence. Such a system must be period of low weed emergence. Such a system must be used with a succession of mostly row crops (to offset costs), where rows are always exactly in the same place.

Fertigation is the water-fertilizer management type of the future. In sandy soils Bar-Yosef and Sagiv (1982) found that total yield was linearly related to total $N$ application rate, when $N$ was applied daily to the irrigation water. In sand Locascio et al. (1989) found that total yields were higher with split trickleirrigation than with all preplant-applied $N$ and $K$, but equivalent on a fine sandy loam. Field experiments on fine sand (Dandler and Locascio, 1990) did not reveal any differences in fruit between fertilizer ( $\mathrm{N}$ and/or $\mathrm{K})$ trickle-injected weekly on a variable (depending on stand stage) or constant schedule; but the latter, if it is simpler to manage, may lead to a lower $N$ use efficiency (Bar-Yosef and Sagiv,

Knowledge about drip irrigation is still fragmentary and sometimes contradictory. In fact, it is difficult to correctly manage. The quantity of water
supply, varying from 40 to $80 \%$ of potential evapotranspiration according to the
studies, depends on soil characteristics and it is the same for water and mutrient studies, depends on soil characteristics and it is the same for water and nutrient (e.g. $N$ and $K$ ) circulation, including losses (Calado et al., 1990). It also depends on soil structure and root system distribution. A structure with good porosity and a deep, dense and healthy rooting are still the main objectives. They may contribute to minimize management mistakes which can very easily occur by supplying either too much or too little water as often seen in farmers' fields, with risks of important yield or quality losses. Rainfall in certain areas adds to the complexity of the
situations.

\subsubsection{Crop protection}

Generally, during this period of time, temperatures are high so that pests are relatively infrequent and weed emergence remains limited. Weed control will consist in stopping the growth of existing weeds, which could be competitive (Solanum sp.), increase soil seed stock and disturb machine harvesting (Amaranthus retroflexus, Chenopodium album, Cirsium arvense, Datura stramonium, etc.). Chemical and some manual interventions are often necessary. Viruses and mycoplasms are detrimental to crops and tolerant or resistant cultivars must be 
used when they exist, as it often is inefficient to try to control their vectors. One of the most yield damaging insect pests is the tomato fruitworm (Heliothis armigera), particularly in late crops. It remains very difficult to forecast and estimate invasion importance even by trapping, and control must be undertaken after observation of eggs on the foliage. This can be an association of chemical and biological techniques, e.g. strong insecticide at the beginning to kill many forms, followed by regular (e.g. weekly) Bacillus thuringiensis sprays (Dumas, 1990 a) or Trichogramma releases. During the phase of important foliage development, pest control will be better ensured by atomised spraying which enables the active ingredient to reach any part of the plants.

\subsection{Ripening phase}

\subsubsection{Concentration of maturity and quality}

Many factors may influence over the whole cycle. Results in literature are not always consistent, particularly about the consequences of nutrient and water availability; this can be explained by the varied experimental situations which generate different interactions. However, the ripening phase conditions are of primary importance.

Maturation must end by crop senescence without regrowth to achieve the concentration of maturity and facilitate mechanical harvesting. This is possible only where low mineral nitrogen and water are available in the soil profile, as generally lower temperatures allow leaf and truss regrowth when fruit demand for assimilates is lower. A better quality (higher soluble solids) requires water shortage during part of the ripening period but also necessitates to maintain a high leaf to fruit ratio. On the contrary, it is necessary to keep plants in functioning conditions as late as possible to let the largest number of fruits grow (high yield). This requires a good water supply, as Wolf and Rudich (1988) found that water stress shortened the duration of fruit growth and accelerated the ripening rate. A good water supply is also needed to maintain late covering foliage to achieve better fruit colour by ripening in the shade of the foliage. All these aspects lead to a difficult compromises in management.

Sander et al. (1989) in California found that yields of red tomatoes increased with increasing trickle irrigation water and the concentrations of soluble solids, total solids and $\mathrm{pH}$ decreased, while colour, fruit size, and acidity increased, as did the yield of soluble solids and total solids per hectare. Many studies have pointed out a conflict between high yields obtained from high water supply and low soluble solid contents. May et al. (1990) suggested managing soil moisture stress either through depletion levels during the cycle or irrigation cut-off dates prior to harvest. The latter factor strongly modified yields and the percentage of solids although solid yield was stable. The choice of the cut-off date will depend on many parameters :- What is the farmer's goal for yield and quality: more fruit per hectare or a higher solid content? - What is the real moisture stress imposed on the crop, as it is related to the available water reserves, including soil moisture content and rooting characteristics? - What will be the intensity of the climatic demand? It is difficult to forecast it beyond 5 days. - What is the crop state (root and foliage health)?

Other quality criteria will have to be considered. Fruit colour is one of them : for example external and internal blotchy ripening of fresh market tomatoes was less severe with trickle-applied $N$ supplied in the form of $N+K$ or $N$ than with preplant-applied $N$ (Dangler and Locascio, 1990). Flavour may be improved, as well as overall fruit quality by salinity from diluted seawater irrigation from the first breaker fruit stage in certain situations without yield loss (Mizrahi et al., 1988). Much is currently known about greenhouse tomato but there is still much to 
be done on processing tomato.

The use of ripening regulators under normal conditions (medium temperatures, recommended doses for slow foliage ageing) favours maturity concentration and quality is not modified (Branthome and Ple, 1990). These aspects have been developed by Leoni (1991, same issue). In fact, faced with consumer pressure, it may become necessary to find ways of cropping without
regulators.

\subsubsection{Crop protection}

Weeds will be removed if they are suspected to disturb harvest or to considerably increase the seed stock. Tomato fruit quality, as measured by soluble solids, acidity and colour, was not influenced by the various weeds or densities in

To keeping fruits with a good aspect on and Montemurro, 1986).

protect the first trusses from overmaturity and plant till harvest it is necessary to appropriate fon trom overmaturity and accompanying diseases by using appropriate fongicide sprays and to protect the foliage from drying up and the fruits from sunburns. But rules on pesticide residues in fruits will be more and more strict. International unity is now indispensable to define the pesticides used and the tolerable residues. It is beginning at the European level. Reducing chemical applications requires the development of predictive systems and using forecast-scheduled spraying. Currently a common solution consists in frequent
observations of test-fields with a warning when thresholds are exceeded.

At this stage of the discussion crop management has reached harvest time, Much has to be done not to decrease quantitative and qualitative production
during harvest, handling and

\section{The place of tomato crop in crop successions}

Crop management must also be thought of in terms of crop succession. Many crops respond positively to "crop rotation" as opposed to monoculture. This seems true for processing tomato. But few experiments or survey studies have yet been performed. Freitas and Faria (1981) found that cropping tomatoes in rotation with maize and beans or with a natural fallow vegetation yielded higher productivity than continuous cropping. Generally speaking, crop specialization trends to increase sensitivity to crop enemies and dependance on chemical control and to increase soil structural degradation by the repeated use of the same soil tillage and crop management methods, often under suboptimal conditions. In France, producers often speak about "soil sickness" when they can no longer achieve good yields in a field in spite of usual management techniques and they usely look for "new fields" where no tomato crop has been grown for at least 20 years. Field surveys showed that "soil sickness" could be associated with the frequency of tomato crops or other vegetables in the succession but not with soil analytical characteristics. "Soil sickness" is not a relevant concept as it may correspond to varied situations caused by different factors which may more or less coexist (Bouhot and Dumas, 1983) : stunted shoot system, low fruit number and low average weight, small root system with necrosis symptoms can be observed as well as weed infestation, high proportion of compact structure in the soil profile, poor
soil fauna (earthworms) and microflora activity. Such situations need a
pluridisciplinary diagnosis, including cropping system. pluridisciplinary diagnosis, including cropping system.

Preceding crops influence the physical, chemical and biological properties of a soil. From a field sample survey, Vergniaud et al. (1984) demonstrated that weed species groups in tomato crops were mainly related to the precedent crops and the weed control methods. It may be profitable to grow tomato after a spring crop
which can safely catalyse the active ingredient of a herbicide very effective on 
Solanum sp. (sunflower, sorghum, soybean, spinach, peas, onions, etc.). Weed suppression may be improved by using allelopathic crops and companion crops in the rotation and by mulching with crop residues. Labrada and Perez (1988) recommended Phaseolus vulgaris, maize, sorghum and cucumber as trap crops for Orobanche ramosa as they stimulated $O$. ramosa seed germination but were not parasitized. On the contrary, forage and cereal crops favour click beetle and McKeown et al. (1988) observed that populations of plant parasitic nematodes were stimulated by rye and strip tillage and that bacterial diseases (Xanthomonas vesicatoria and Pseudomonas tomato) were increased by strip tillage in one season. As a positive nutritional aspect, residual $N$ from a sugar beet crop had a greater impact on tomato yield than fertilizer applied specifically to that crop, and crop rotation and efficient fertilization practices could minimize $\mathrm{N}$ losses by leaching (Osterli and Meyer, 1977). In this context, organic matter must not be forgotten and residues of certain crops in the succession may be useful for micro-fauna and flora activity (soil structure) and to conserve chemical fertility, e.g. for $\mathrm{N}$ and $\mathrm{P}$ if fertilizer supplies are low.

There is a need to study the effects of previous crops on the medium and the consequences on the following crop management. The farmer's practices (land preparation and crop management) tend to favourably modify the medium characteristics for tomato. But instead of simply enduring and correcting them by using many expensive techniques, it may be possible to try to better control the previous crop management to achieve a field state more favourable to tomato in terms of soil structure, nutrient status, weeds, pests and diseases, etc. Of course the choice of crops is the farmer's responsibility and depends on the physical and socio-economic context. But in the future these aspects must be kept in mind and better controlled in integrated cropping systems. Long term evaluation of cropping system effects on yield and on environment should be performed.

\section{Future viewpoint for growers and researchers}

There is some distance between growers and researchers. Growers think about their practices for tomato crops within a constraint framework at the farm level which includes problems of equipment, time distribution of the work, financial availabilities, personal work or life style, etc. They have to solve synthetic problems and often make decisions in relation to the whole farm management rather than crop by crop. On the contrary researchers tend to reason more analytically at the single crop level in a field during a season independantly of farming situations. Collaboration between researchers and growers should occur in two directionss : developments of tools to measure indicators and forecasting.

Growers' attitude will probably change gradually. They will have to find more time to observe, to measure parameters and to keep informed, to be able to diagnose, forecast and finally decide. To do this well they will need indicators on soil and plant states, which can easily be used. In some cases decision-making may automatically originate from data collected by sensors in relation to a predetermined threshold. Growers will need to learn, but their acceptance of innovation will no doubt be difficult, as many of them will have to reformulate or reinvent the new technology by themselves (Grieshop et al., 1988) or through discussions inside their professional group.

\subsection{Tools for indicator measurements}

There already exist tools to help decision-making but they are not always practical on the farm. Irrigation is among the more advanced chapters. A great effort has been made to promote irrigation assistance systems by scheduling based on predicted or directly measured soil or plant water status. Various principles 
have been utilized. The water balance model requires information on root water extraction activity throughout the soil profile, canopy state, crop coefficients and climatic data; it may be linked to a regional agrometeorological assistance system. Soil water status may be estimated using a neutron probe or more commonly tensiometers; but with drip irrigation systems the difficulty lies in placing tensiometers correctly due to specific moisture distribution, and many mistakes are made by growers in addition to problems of going off scale. Han (1988) found that the climatological method was as accurate as the neutron probe method and was more convenient and less expensive; but few growers use it essentially because it is "too complicated" (Wolfe, 1990). Growth stage and root depth observations are time consuming and errors associated with root depth estimation may limit the accuracy of ET estimates. But there are also other promising approaches for the future. Real time scheduling with automated soil matric potential sensor measurements was successfully experimented on by Phene and Clark (1990). Crop Water Stress Index (CWSI) quantifies plant water stress by measuring plant canopy temperatures with an infrared thermometer (Calado et al., 1990) and appears to be useful in irrigation management. Measurement of leaf water potential or micrometric organ (stem or fruit) size variations (Huguet, 1985) are other possibilities. Remote sensing from airplanes or satellites with connexions to computers and automatic equipments will be a further step which will even make it possible to determine what kind of stress a crop is undergoing (water deficiency or excess, nutrition, disease, pest, etc.). But it will be a long time before all these sophisticated technologies can reach farms. Within the next ten years more growers will probably be using microcomputers and consultants for crop management but only if they find truly user-friendly programmes for scheduling. Scheduling software conception is difficult because it must be easy to use and yet complex enough to maintain accuracy. That is why in the near future education that emphasizes the simplest guidelines and concepts should be continued for most growers.

As for fertilization, measurements on plants or soil are difficult and unautomatized. There are no indicators with rapid responses and there are few models generally adapted to very particular situations. However, estimated balances are needed in relation to objectives and unpredictable events.

Crop protection is also difficult to forecast. Expert systems are being developed for more reliable diagnosis. But the tendency is still more towards anticipation or preplanned routine spray schedules than spraying on-demand when necessary, because of the high risks. Progress is expected to find new specific and systemic ingredients which react at very low doses, to use biological control (natural enemies regulating pest populations) and above all to develop genetic resistance. The key for success will lie in an "integrated pest management" efficiently using available strategies to control populations at an acceptable level with a minimal use of chemical pesticides.

It is important to note that an efficient use of all these various sensors requires some knowledge of the whole set of parameters i.e. requires modeling the crop as a whole.

\subsection{Aids for decision-making}

Formerly, cropping utilized traditional methods established over a long time period through trial and error successions and included the main possible environment variations. Most of the available studies have dealt with specific topics in particular situations; they often reported results that varied from year to year or place to place and it remains difficult to establish general relationships between these results due to the large number of variables involved: cultivar, planting date, global radiation, water and nutrient availability, impact of pests, etc. 
There is a need for synthetic studies and theorization. It is necessary to "manage" the crop towards a final aim through a succession of sub-objectives without failing. Researchers have to propose "estimated crop management schedules" which could integrate parameters on field history determining its initial state before tomato, grower's means and farm functioning, average climate and risks of extreme events, production objectives and objectives of future utilization of the field. Modeling is expected to help provide simulations before decision-making. Many studies have been started in this direction over the past few years, but essentially under greenhouse conditions. Management requires predictive models based on crop physiology and environment characteristics (Wilson et al., 1987) i.e. operational tools for work close to the field conditions. It seems important to pay attention to the variability of both soil and plant canopy over space and time (Bussières, 1990). This of course involves interdisciplinary research to organize the scattered knowledge into consistent and quantitative schemes. More and more complex situations will also require research to be developed at the farm level.

\section{Conclusion}

All the partners involved in field production process must be aware that cropping for the highest yield is no longer the only goal. Research and Development Services now have to work to promote integrated cropping systems. They must get ready for the enforcement of next legal measures to severely reduce pesticide and fertilizer use. New production systems will have to guarantee their own viability with little or no output to the environment and without risks for the consumer, to maintain soil fertility and generate an acceptable income for the grower. These systems will involve a high input of available knowledge to produce better food in a better and more economical way.

Advanced technology management will undoubtedly be more often adopted in developed countries, particularly in areas favourable to production (large farm structures, good physical and economic environment) which may cause some changes in the distribution of production areas. On the other hand, it is expected that less developed regions may somewhat compensate for their technical backwardness, as they will be able to take advantage of the available knowledge for rational crop management without experiencing a period of high productivity with its disadvantages in terms of use of excessive quantities of chemicals and energy.

Acknowledgements: I wish to express grateful thanks to Ph. Bussières for his critical reading of the manuscript.

\section{References}

Alvarado, A.D., Bradford, K.J. and Hewitt, J.D., 1987. Osmotic priming of tomato seeds : effects on germination, field emergence, seedling growth, and fruit yield. J. Amer. Soc. Hort. Sci. 112 (3): 427-432.

Argerich, C.A. and Bradford, K.J., 1989. The effects of priming and ageing on seed vigor in tomato. J. Exp. Bot. 40 (214): 599-607.

Argerich, C.A., Bradford, K.J. and Ashton, F.M., 1990. Influence of seed vigor and preplant herbicides on emergence, growth, and yield of tomato. HortSci. 25 (3): 288-291.

Barlow, E.W.R. and Haigh, A.M., 1987. Effect of seed priming on the emergence, growth and yield of UC 82B. Acta Hort. 200: 153-164.

Bar-Yosef, B. and Sagiv, B., 1982. Response of tomatoes to $\mathrm{N}$ and water applied via a trickle irrigation system. I. Nitrogen. Agron. J. 74 (4): 633-637. 
Bouhot, D. and Dumas, Y., 1983. Fatigue des sols en culture de tomates de plein champ. in La fatigue des sols, 23eme colloque SFP, Les Colloques de

Branthome, X. 1990. Lutte raisonné contre les mauvaises herbes dans les cultures de tomates d'industrie. Acta Hort. 277: 103-114. Branthome, X. and Ple, Y., 1990. Intérêt et limites de l'utilisation des régu-
lateurs de maturité. Acta Hort. $277: 69-75$.

Bues, R., Toubon, J.F., and Poitout, H.S., 1985. Elaboration d'une lutte raisonnée contre les pucerons (Macrosiphum euphorbiae Thomas et Mysus persicae Sulzer) en cultures de tomates de conserve dans le sud-est de la France. Proc. Workshop WPRS/OILB and EEC group on Integrated Plant Protection in field vegetables pp 15 .

Bussières, $\mathrm{Ph} ., 1990$. Canevas de modèle d'une ligne de plantes de tomate semées explicitant sa variabilité spatiale. Acta Hort. 277: 221-227.

Caussanel, J.P., Abd el Fatah, H., Branthome, X., Maillet, J. and Jacquard, J. 1989. La concurrence morelle (Solanum sp.) * tomate (Lycopersicon esculentum Mill.) : résultats expérimentaux obtenus en France. EWRS, 4ème Calado A M Mediterranéen de Malherbologie 2: 33-45.

Monitoring and control of plant water stress., Ma, C., and Wang, Y., 1990 Hort. 277: 129-136.

Calado, A.M., Portas, C.M., and Ferreira, A.G., 1990. Mobility of nitrogen, phosphorus and potassium in sandy soils in tomatoes for processing. Firenze (Italy).

Coltman, R.R., 1987. Sampling considerations for nitrate quick tests of greenhouse grown tomatoes. J. Amer. Soc. Hort. Sci. 112 (6): $922-927$.

Damato, G. and Montemurro, P., 1986. Studio della competizione fra Solanum nigrum L. e pomodoro da industria trapianto. Difesa delle Piante 9 (4): 359 .

Damidaux, R., Galvez, F. and Branthome, X., 1990. Comportement de lignées sauvages de tomate vis à vis d'herbicides efficaces sur Solanum nigrum. 14 ème Conf. du COLUMA, journées internationales d'études sur la lutte contre les
mauvaises herbes, pp 7 (in press)

Dangler, J.M. and Locascio, S.J., 1990. External and internal blotchy ripening
and fruit elemental content and fruit elemental content of trickle-irrigated tomatoes as affected by $\mathrm{N}$

Dangler, J.M. and Locascio, S.J., 1990. Yield of trickle-irrigated tomatoes as

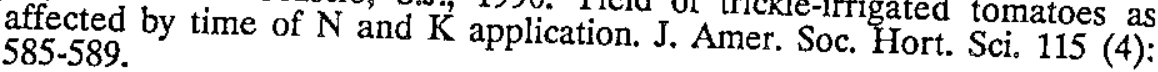

Di Candilo, M. and Casarini, B., 1987. Pomodoro da industria : motivazioni e tecniche per la meccanizzazione della recolta. L'Inf. Agrar. 8: 29-69.

Dumas, Y., 1982. Variation de la hiérarchie des principales composantes de la fertilité en fonction des cultures. Cas des cultures légumières de plein

Dumas, Y., 1989. Pour une fertilisation.

ture mécanisée de la tomate de conserve Plus efficace et moins con̂teuse : cul-

Dumas, Y., 1990 a. Mechanization and inp.H.M.-Rev. Hort. 294: 57-69. cropping : agronomic aspects; building and testing of processing tomato ways of management. Acta Hort. 277: 145-154. Dumas, Y., 1990 b. Tomatoes for processing in 90 's : nutrition and crop ferti-
lization. Acta Hort. $277: 155-166$.

Duranti, A and Carone, F., 1983. Rapporti di competitività tra pomodoro seminato (Lycopersicon esculentum Mill. cv. "Petogro") ed infestanti. Rev. Or-
tofl. Ital. 67 (3): 191-207. 
Freitas, M.B. de and Faria, C.M. de, 1981. Influéncia de práticas agrícolas na fertilidade do solo e no rendimento do tomateiro no agreste pernambucano. Revista Brasileira de Ciência do Solo 5 (1): 54-57.

Frost, D.J. and Kretchman, D.W., 1988. Plant spatial arrangement and density effects on small- and medium-vined processing tomatoes. J. Amer. Soc. Hort. Sci. 113 (1): 51-55.

Gerber, J., 1981. Direct seeding tomatoes: the future is here. American Vegetable Grower 29 (12): 6-7.

Grattan, S.R., Schwankl, L.J. and Lanini, W.T., 1988. Weed control by drip irrigation. Cal, Agr. 42 (3): 22-24.

Greenwood, D.J., Kubo, K., Burns, I.G. and Draycott, A., 1989. Apparent recovery of fertilizer $N$ by vegetable crops. S. Sci. P1. Nutr. 35 (3): 367-381.

Greig, J.K., Fogleman, M.E. and Wittsell, L.E., 1964. Soil compaction effects on transplanted tomatoes. J. Amer. Soc. Hort. Sci. 85: 490-496.

Grieshop, J.I., Zalom, F.G., and Miyao, G., 1988. Adoption and diffusion of integrated pest management innovations in agriculture. Bull. Entom. Soc. Am. 34 (2): 72-78.

Haigh, A.M. and Barlow, E.W.R., 1987. Germination and priming of tomato, carrot, onion, and sorghum seeds in a range of osmotica. J. Amer. Soc. Hort. Sci. 112 (2): 202-208.

Han, C.S., 1988. Comparison of irrigation schedules for processing tomatoes based on soil moisture measurement and climatological data. Acta Hort. 228: 91-96.

Huguet, J.G., 1985. Appréciation de l'état hydrique d'une plante à partir des variations micrométriques de la dimension des fruits ou des tiges au cours de la journée. Agronomie 5 (8): 733-741.

Labrada, R. and Perez, R., 1988. Medidas de lucha no química contra Orobanche ramosa. Agrotecnica de Cuba 20 (1): 35-40.

Lecocq, A. and Vayson, A, 1985. Les prévisions d'apports de tomate en usine. in Agrométéorologie et Productions légumières. Les Colloques de l'INRA. n 33 : 111-124.

Leskovar, D.I. and Sims, W.L., 1987. Emergence and yield of tomato (Lycopersicon esculentum Mill.) in response to presowing treatments. Acta Hort. 200: 145-152.

Locascio, S.J., Olson, S.M. and Rhoads, F.M., 1989. Water quantity and time of $\mathrm{N}$ and $\mathrm{K}$ application for trickle-irrigated tomatoes. J. Amer. Soc. Hort.Sci. $114(2): 265-268$.

May, D.M. and Valencia, J., 1990. Single versus double row spacing of six processing tomato cultivars. Acta Hort. 277: 97-102.

May, D.M., Wolcott, T., Peters, D., and Grimes, D.W., 1990. Moisture stress as it affects yields, soluble solids and viscosity of tomatoes. Acta Hort. 277: 123-128.

McKeowm, A.W., Cerkauskas, R.F., and Potter, J.W., 1988. Influence of strip tillage on yield, diseases, and nematodes of tomatoes. J. Amer. Soc. Hort. Sci. 113 (3): 328-331.

Mizrahi, Y., Taleisnik, E., Kagan-Zur, V., Zohzr, Y., Offenbach, R., Matan, E. and Golan, R., 1988. A saline irrigation regime for improving tomato fruit quality without reducing yield. J. Amer. Soc. Hort. Sci. 113 (2): 202-205.

Monaco, T.J., Grayson, A.S., and Sanders, D.C., 1981. Influence of four weed species on the growth, yield and quality of direct-seeded tomatoes. Weed Sci. 29 (4): 394-397.

Nichols, M.A., Nonnecke, I.L. and Phatak, S.C., 1973. Plant density studies with direct seeded tomatoes in Ontario, Canada. Sci. Hort. 1 (4): 309-320.

Osterli, P.P. and Meyer, J.L., 1977. Crop rotation improves nitrogen utilization. California Agriculture 31 (2): 7 . 
Phene, C.J., Davis, K.R., Hutmacher, R.B. and McCormick, R.L., 1987. Advantages of subsurface irrigation for processing tomatoes. Acta Hort. 200: 101114.

Phene, C.J. and Clark, D.A., 1990. Real time irrigation scheduling with automated soil matric potential sensor measurements. Acta Hort. 278: 395-405.

Phene, C.J., Hutmacher, R.B., Davis, K.R. and McCormick, R.L., 1990. Waterfertilizer management of processing tomatoes. Acta Hort. 277: 137-143.

Portas, C.M., Branthome, X., Ple, Y. and Calado, A.M., 1990. Tomatoes for processing in the 90's : agricultural field practices. Acta Hort. 277: 83-96.

PuIs, E.E. and Lambeth, V.N., 1974. Chemical stimulation of germination rate in aged tomato seeds. J. Amer. Soc. Hort. Sci. 99 (1): 9-12. Putman, A.R., 1990. Vegetable weed control with minimal herbicide inputs. Hort
Science 25 (2): 155-159.

Ruff,M.S., Krizek, D.T., Mirecki, R.M. and Inouye,D.W., 1987. Restricted root zone volume : influence on growth and development of tomato. J. Amer. Soc.
Hort. Sci. 112 (5): 763-769.

Sanders, D.C., Howell, T.A., Hile, M.M.S., Hodges, L., Meek, D., and Phene, C.J., 1989. Yield and quality of processing tomatoes in response to irrigation rate and schedule. J. Amer. Soc. Hort. Sci. 114 (6): 904-908. Siviero, P, 1990. Planification de la culture de la tomate en fonction de la
récolte mécanique. Acta Hort. $277: 77-82$.

Stoffella, P.J. and Maynard, D.N., 1988. Stand deficiencies and replanting effects on tomato fruit yields and size. J. Amer. Soc. Hort. Sci. $113(5)$ :

Suniaga, J. and Dumas, Y., 1990. Mineral nutrition of tomato after germination. Influence of nitrogen on initial growth. Abstracts of contributed papers, 1. Oral, 1583. XXIII Int. Hort. Cong., Firenze (Italy).

Suniaga Quijada, J., 1990. Nutrition azotée de la tomate semée pendant la phase juvénile. Effets de différentes concentrations d'azote sur la croissance
et le développement. Acta Hort. 277: 167-177.

Vergniaud, P., Maillet, J., Abd el Fatah, H., and Boneff, M., 1984. Influence des techniques culturales sur les peuplements d'adventices des cultures de tomate dans la basse vallee du Rhône. Proc. EWRS 3rd Symposium on Weed
Problems in the Mediterranean Area 2: 381-388.

Wallace, A, and Abouzamzam, A.M., 1986. Interactions of soil conditioner with other limiting factors to achieve high crop yields. Soil Science 141 (5):
343-345.

Weaver, S.E., Smits, N. and Tan, C.S., 1987. Estimating yield losses of tomatoes (Lycopersicon esculentum) caused by nightshade (Solanum spp.) interfe-

Weaver, SE and Tan (2): 163-168. field-seeded tomatoes and 1987. Critical period of weed interference in PI. Sci. 67 (2): 575-583.

Widders, I.E. and Lorenz, O.A., 1979 Tomato root development as related to potassium nutrition. J. Amer. Soc rot de

Wilson, L.T. Gutierrez. . Amer. Soc. Hort. Sci. 104 (2): 216-220. logical based model for processing tomato and Zalom, F.G., 1987. A physioHort. 200: 125-132.

Wolf, S. and Rudich, J., 1988. The growth rates of fruits on different parts of the tomato plant and the effect of water stress on dry weight accumula
tion. Sci. Hort. $34(1 / 2): 1-11$.

Wolfe, D.W. 1990. The challenge : expanding the utilization of irrigation scheduling principles. Acta Hort. 278: 879-886. 
Table 1. Compared changes in guaranteed minimum hour wage and the selling price of $1 \mathrm{Kg}$ of tomato for paste in France.

\begin{tabular}{|lrrrrrrr|}
\hline & 1978 & 1980 & 1982 & 1984 & 1966 & 1988 & 1990 \\
\hline a Guarantead & & & & & & & \\
mininum wage (FF) & 10.85 & 14.00 & 19.64 & 23.84 & 26.92 & 28.76 & 31.28 \\
Relative index & 100 & 129 & 181 & 220 & 249 & 265 & 268 \\
B = Towato price (EF) & .41 & .53 & .61 & .69 & .66 & .67 & .70 \\
Relative index & 100 & 125 & 150 & 168 & 160 & 263 & 171 \\
A/B & 26.6 & 27.4 & 32.1 & 34.6 & 41.1 & 43.2 & 44.6 \\
Relative index & 100 & 103 & 121 & 130 & 155 & 162 & 169 \\
\hline
\end{tabular}

Table 2. Crop planning and year to year climate variability: some schematic types of likely situations in the South-East of France.

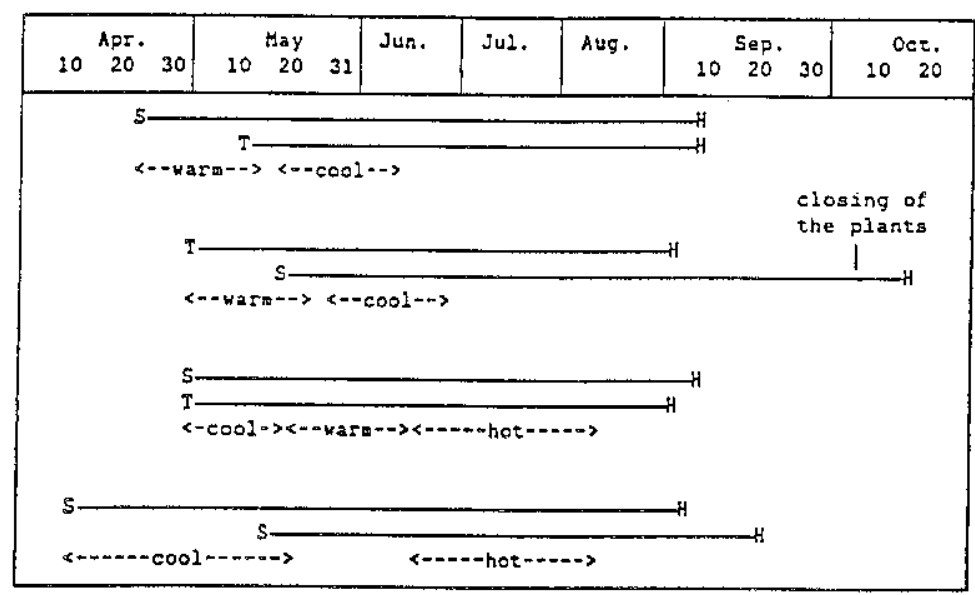

$S=$ aeecing

$T=$ transplanting

h = harvesting

Table 3. Yield components $\left(\mathrm{Y}_{\mathrm{O}}=\right.$ "quantitative" point of view; $\mathrm{Y}_{\mathrm{q}}=$ "qualitative" point of view, e.g. soluble solids) and main development phases of determinate tomato for paste.

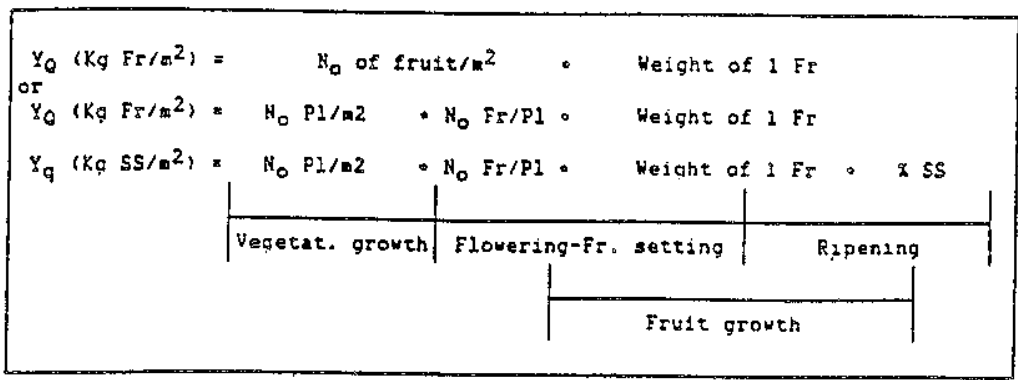



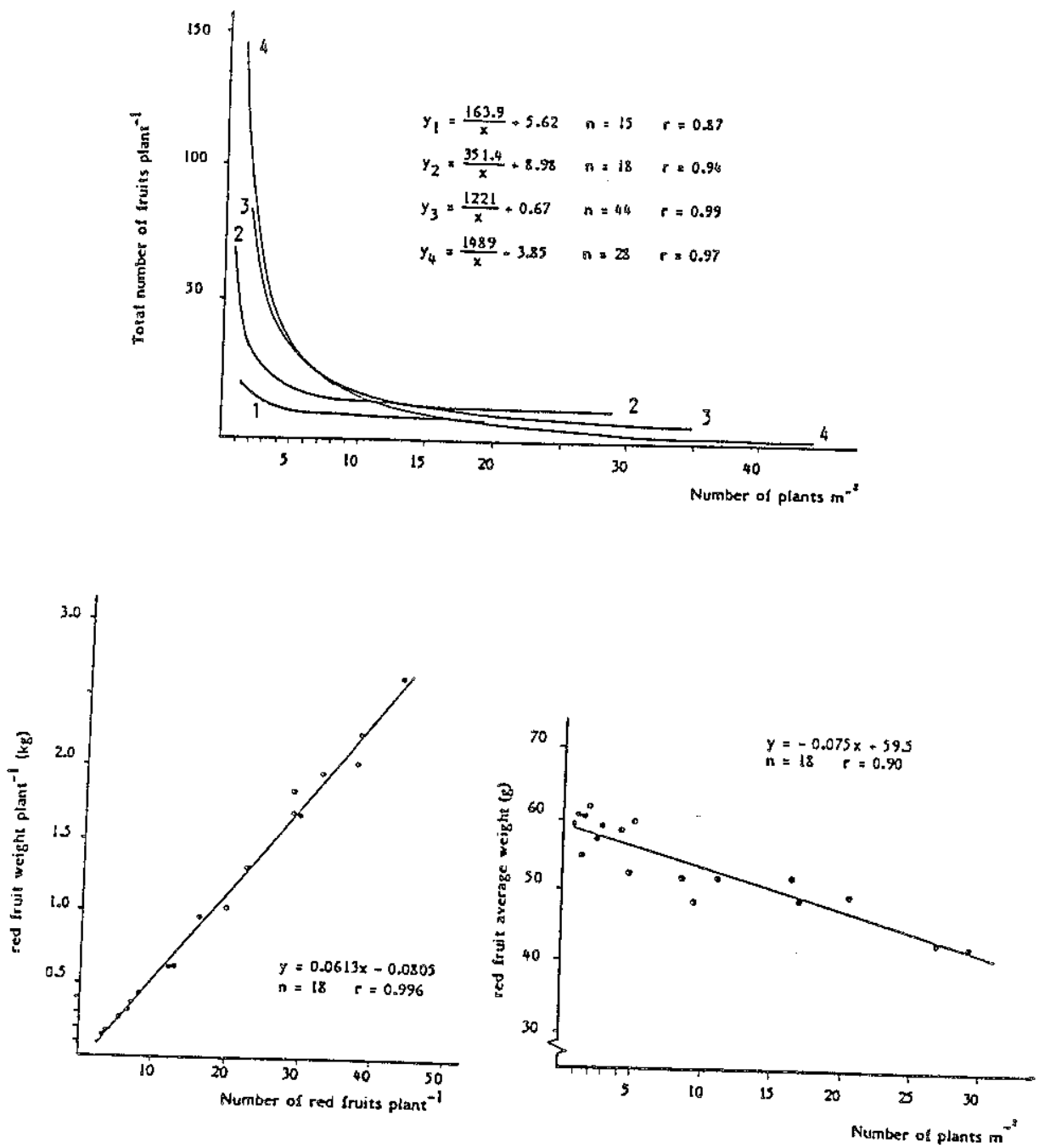

Figure 1. Influence of plant spacing on the tomato yield components in various situations of farm crops (cultivar UC 82) labelled 1, 2, 3 and 4 . Density ranges were obtained by thinning stands emerged at a very high density in
similarly managed fields on loamy clay soils.

Above : variability of stand responses to plant spacing. yield component in crop 2 .

ent in crop 2 left : number of red fruits plant 1 as the main

Below on the right: individual fruit weight response to
in crop 2 . plant spacing in crop 2 . 


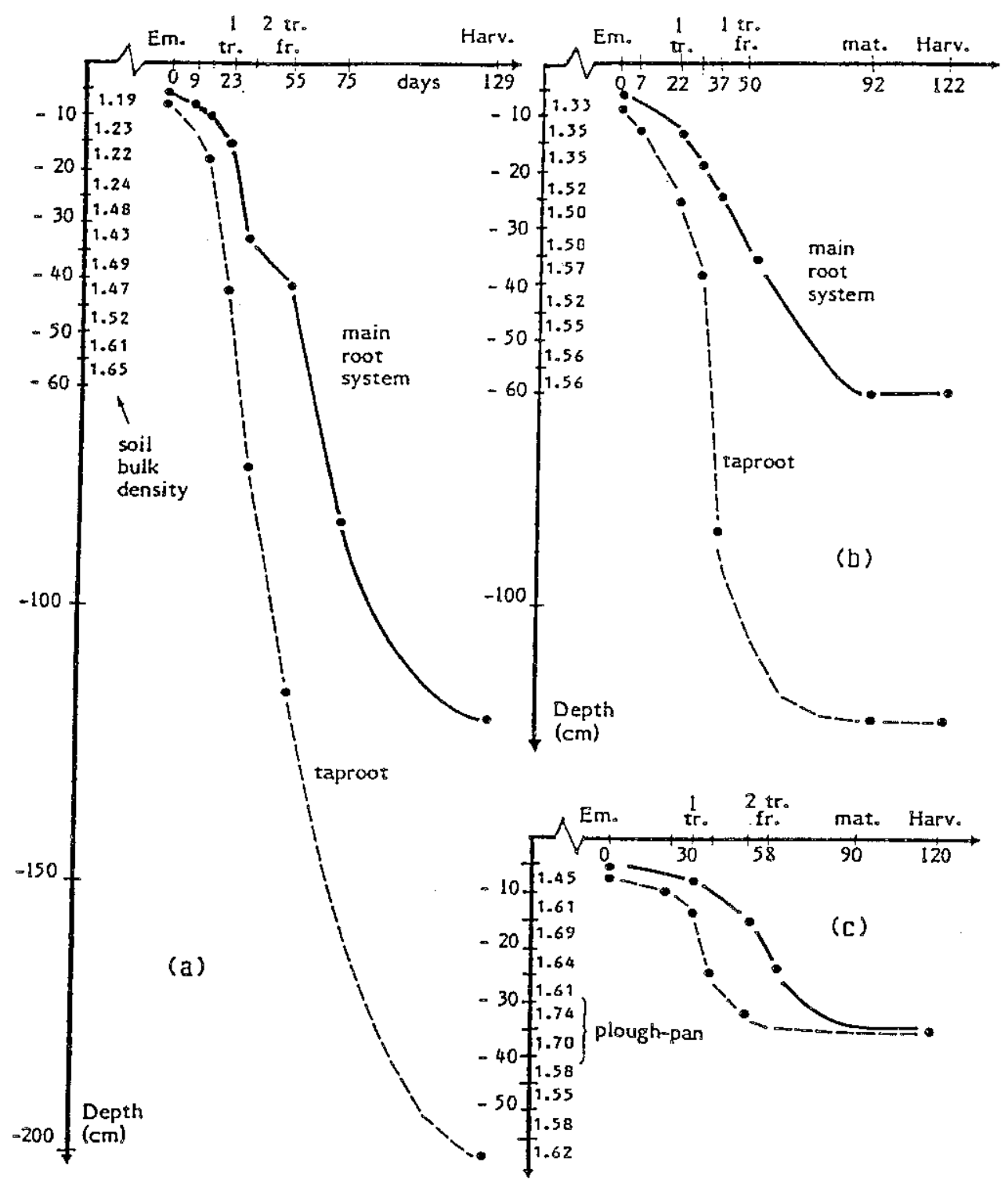

Figure 2. Influence of soil structure, particularly soil bulk density, on the depth of the tomato root system (cultivar UC 82) in loamy clay soils for three contemporary farm crops labelled (a), (b) and (c) (for comments see the text, section 3.1.3.). 